\title{
ATTEMPTS BY MNCS TO EXPAND THE CREATIVE AND INNOVATIVE SPIRIT THROUGH THE CONCEPT OF AGILITY: ROLE OF GLOBAL MANAGERS
}

\author{
Montenero, V., Cazorzi, C.
}

Vincent Montenero / Masaryk Institute of Advanced Studies, Czech Technical University in Prague, Kolejni 2637/2a, 16000 Praha 6, Czech Republic. Email: vincent.montenero@cvut.cz

Cristina Cazorzi / PSL University, DRM lab M\&O Place du Maréchal de Lattre 75775 PARIS Cedex 16, France.Email: ccazorzi@gmail.com

\begin{abstract}
Faced with an environment that is changing faster and faster, companies have long sought to encourage the almost automatic emergence of new approaches that can respond or even anticipate these changes. The development of creativity has become an essential theme. For more than 20 years, companies have been promoting the concept of agility at the same time as they attempted to extend creativity to all employees. Managers have been called upon to implement the corresponding actions. Our research, based on semi-structured interviews with 35 global managers, analyses several aspects of the implementation of the concepts. We looked particularly at what managers think of agility, how this concept relates to the efforts made to develop creativity, what they experienced, and the conditions for success. The analysis of the responses highlights the significant differences in perception, often linked to the functions performed in the company or to nationalities. Regardless of the value associated with agility, the interviewees agreed on the importance of the manager's role while directing it in three different directions. The discussions also identify a series of necessary but not sufficient conditions for creativity to emerge.

Implications for Central European audience: This paper does not deal with a problem specific to Central Europe. It is a general problem going beyond regional limits, as international management tends to use the same concepts everywhere. However, in its processing, we sought to interview several managers from this geographic area. In the second phase, we plan to improve the representativeness of managers from Central Europe to understand better what is specific to them.
\end{abstract}

Keywords: management; agility; creativity; innovation; national cultures JEL Classification: M16, O39, L29

\section{Introduction}

From the very start of its existence, each company develops a specific organisational culture that results from the combination of several factors. Among the most significant, we find the local or national referential frames of the area where it came to life, the norms and rituals taken 
as models, the individual values of the founder, or the conditions of the initial breakthroughs. The culture evolves based on significant changes and events (Schein, 1990; Smircich, 1983; Wei Zheng et al., 2010). When the internal or external contexts press corporations to change, the values contained in the organisational culture may help companies to adapt. Moreover, Top Management may attempt to develop the employees' ability to innovate through training or even by instilling new values.

Throughout their daily operations, managers usually refer to organisational culture, or better to the values involved, to manage their teams (Schein, 2010). When practices need to evolve, leaders carry, among other things, the growing burden of implementing these changes and supporting their teams (Caligiuri et al., 2013). In so doing, they play a significant role in preparing MNCs to face the challenges of the future. Yet, the Directions see this last feature as being increasingly important because of the rapidly changing environment. This latter evolution is the primary official reason why, for more than 20 years, Top Management has defined actions that could enhance the employees' flexibility or better their creativity, i.e., to help them "think out of the box" each time that it is necessary. This action has gone in several directions, starting with the development of the concept of "agility" (Sherehiy et al., 2007) and reaching out to more complex creativity programs.

We base our research on the interviews of international managers working in highly globalised MNCs. This exercise stems from our conviction that observing the complexity of the MNCs' environment is essential to understand how the global leaders act, between local roots and global trends (Cazorzi, 2018). More precisely, we focus on a better understanding of the role of leaders in the enhancement of creativity. Our interest in this matter results from our personal experience as international managers and from the fact that we have seen the function gradually evolve and become more complex.

Among other things, the industry has been long using the concept of agility as one of the fundamental corporate values or as the symbol of ideas implemented to facilitate decisionmaking and the emergence of innovative solutions. This frequency of use hides a significant ambiguity as it is not clear whether all managers understand the idea in the same way or whether they give it equal importance. Despite becoming a buzzword, the idea behind it was still a necessary step towards a form of extended creativity that is no longer the prerogative of a reduced number of individuals within the company. While the Directions consider this development essential, they tend to add the task to what international managers are supposed to do, leaving us with three open questions. How can this evolution effect managing patterns? What are the conditions of success? And how can we solve the inevitable opposition between the need for innovation and the corporations' propensity to reduce risks?

We consider that this text is a first work, a kind of pilot. We wish later on to improve the representability of our sample to go further in the search for more meaningful correspondences concerning the different types of cultures, the areas of activity, and managers' categories. After focusing on the literature on agility, creativity, and innovation, we shall detail the methodology that we used. We will then look at the first results of our analysis before concluding with a discussion highlighting the items that we could establish and the open questions. 


\section{Frame of reference}

Creativity is the process that allows one to form something new and somewhat valuable (Lee \& Mumford2003; Mumford, 2003). If there is a general agreement on the primary process, scholars dramatically diverge when we go deeper into its description and outcomes. Many usually consider that creativity is the operation leading to ideas, whereas innovation is their actual implementation (Amabile \& Pratt, 2016). In the business world, Schumpeter contributed significantly to the study of innovation economics, arguing that industries must revolutionise permanently the way they approach their markets and engage in "creative destruction" (Grahl, 1985). At the centre of the process, we find here the "entrepreneurs" who push their ideas to the rest of the organisation (Harrison, 2012). Later theories kept a linear perception but introduced the feedback, opening the way to models based on networking.

Creativity usually is present in a higher flexible system, where diversity is broadly accepted, and openness of the mind receives a significant value (Aretz \& Hansen, 2003a). In Aretz's "flexishape model," it becomes possible to adapt to the context through freedom to act with different processes, as well as a general acceptance of failure.

Whatever their functions, global managers (located at headquarters or abroad) are obliged to adapt their manners to a fluid world. Moreover, to survive, they should not be disoriented by complexity (Barro \& Lee, 2015; Chakravarty et al., 2013; Sambamurthy et al., 2003; Tan et al., 2017; Zain et al., 2005). For the organisation of enterprises, the primary challenge was, is, and will be to accept to essay new routes and change them very fast, i.e., to be mistaken and modify the approach whenever necessary (Aretz \& Hansen, 2003b).

Creativity is not only the sum of personal and individual efforts but also what teams can do (Paulus \& Nijstad, 2019; Zheng et al., 2010). Above all, it is not only a specific feature found in a limited number of persons, since anyone can contribute to creating some habitual innovations (Ettlie, 2019; Glăveanu, 2015, 2017). In literacy, we often find the words creativity and innovation together as if they were synonyms. But in reality, creativity should only refer to launching new ideas (Amabile, 1996) whereas innovation represents the application of the new frame and procedures (Fetrati \& Nielsen, 2018; Rosing et al., 2011).

Encouraging creativity is a significant point in managing a team and a fundamental question to the manager. Organisations have substantial challenges in companies' results (Ettlie, 2019; Glăveanu, 2015, 2017). In effect, too much bureaucratic control can block the natural creativity and the application of new procedures (Machado \& Miranda, 2020; Mohamed et al., 2019). Creativity obliges managers to accept some forms of shared responsibility and equity (Bouwman et al., 2018; Kirton, 2004; Tan et al., 2009; Thiruvenkadam \& Kumar, 2018).

Getting back to the elements described by Schumpeter on the cycles of innovation, Alter (2015) has defined an interesting theory based on the idea that work situations today are much more linked to movement than to stability. According to this perception, innovation is a movement that concerns all players within organisations and which can create a new behavioural norm. Yet, when it takes place in large organisations, this movement finds itself in a partial confrontation with the organisation. It is essential to note that this form of innovation happening in large corporations is not supposed to bring actual revolutions, but it takes the form of a continual process of gradual change. We can remind here that literature distinguishes two types of creativity: radical creativity consists of developing entirely new methods and products. In 
contrast, incremental creativity involves relatively small changes to the existing ideas, processes, and products (Madjar et al., 2011).

For many years, Japan was leading the way of all attempts relating to radical innovation (Ouchi, 1980; Pesqueux \& Tyberghein, 2010). In the West, since the early nineties, many large groups have been worried by the extreme speed of market changes, considering it essential to increase the employee's capacity to react better and answer to internal and external factors.

On top of creativity, which allows us to invent new products and processes, MNCs developed the concept of "agility" to increase their responsiveness and be able to find solutions for unexpected problems. Over the past 15 years, industrial groups of different nationalities have put the idea of "agility" at the heart of the leadership programs they defined. We can primarily link the emergence of this concept to the fast globalisation of the world economy, as well as to several specific multinational companies (General Motors, Daimler, Ford, Thompson, not forgetting Nasa). These corporations clearly stated their need to find new solutions to address the increasingly fast-moving changes (Khan \& Wisner, 2019; Narel et al., 2019).

For managers, this was translating with the idea of keeping the same level of team efficiency despite internal and external changes (Bhatt et al., 2010; Chakravarty et al., 2013; Chen et al., 2014; Khan \& Wisner, 2019; Roberts \& Grover 2012; Swafford et al., 2008; Tallon \& Pinsonneault, 2011; Vickery et al. 2010)

An essential aspect of agility, as opposed to past approaches, is that it is not only a few people with high creativity who are supposed to carry the system but all employees under the international managers' supervision.

\section{Methodology}

Our empirical study aims at exploring practices used by global managers to foster creativity and innovation, either as part of what is required by the Boards or on the managers' initiative. We are using a qualitative approach based on semi-structured questionnaires. To do so, we asked the interviewees to describe what they think about the concept of "agility" and how they live it on a day-to-day basis. We also asked them to explain how they foster creativity in their teams or outside and how they reached innovations. As we did not use closed questions, we consider it almost impossible to give precise percentages of the interviewees' opinions. Instead, we deduced the interviewees' views according to our interpretations of the whole discussion. We show in Table 1 the details of the questions asked. 


\begin{tabular}{ll} 
Topic & \multicolumn{1}{c}{ Main questions } \\
\hline Agility & What do you think about the feature "agility" often used today by international \\
& companies? \\
& How does this feature influence your action today? Your form of management? \\
& How can this feature influence your action tomorrow? Your form of management? \\
\hline Creativity & Do you think that it is essential for global managers to enhance creativity? Why? \\
& Is it limited to your team, or does it affect other persons? \\
\hline Innovation & Can you give examples of actions that you have implemented to enhance innovation? \\
& What are the conditions for this to work?
\end{tabular}

Source: authors

Besides issues dealing with agility, creativity, and innovation, the interviews also intended to understand what the main perceived challenges of the function were and what the respondents thought about the necessary qualities to be successful in the job. We ended with questions investigating the area of identity,i.e., whether they still identified themselves as linked to a specific country or continent after working for many years in a global environment.

To write this paper, we used data coming from the interviews of 35 international managers, and we intend to interview eventually eighty persons to have the best possible representative mix of world regions and activities. Around $70 \%$ of the interviews were conducted in person, whereas most of those performed remotely concerned managers located outside Europe. Interviews lasted between 60 minutes and 100 minutes. Whenever possible, we held them in the working language of the person concerned. To do so, we left most freedom to the person to decide what they considered their working language to be: this is the reason why the language used for several Italian or French-speaking managers was English.

All respondents performed a managerial function in an international environment. They were located in foreign subsidiaries or working in central roles (headquarters). $60 \%$ of the total were expatriates or had an expatriate experience in the past. In the few cases where they were exercising a local function, it was merely a necessary step in a mainly international career.

We mention the official nationality of the companies, while it is always difficult to establish whether this has a real impact. In some instances, the group to which they belong had an essential influence on the processes in place. We can mention the example of the strong implication of the German Volkswagen in the case of Skoda or, on the contrary, the absence of a significant Russian connexion for Gefco. Nowadays, the influence of the original nationalities of companies is most of the time offset by several acquisitions or restructuring, making it difficult to understand the correlations between the national origin and the organisational culture resulting from history. We may have surprising combinations, such as for Whirlpool, a strongly regionalised American company that is highly dominated by Italians in Europe. In the same veins, it might be challenging to identify the influence of the industry on the way managers operate. While we found very few striking evidence of the relations between personal identity, the work location, and the original corporate culture, we hope to be able to attain better results in future analyses.

For the sector of activity, we decided to interview managers working in highly globalised industries such as automotive, aeronautics, or the mass production of household equipment. 
We chose to avoid service activities or small-sized companies, which may have quite a different approach to management or requirements.

The interviews were transcribed and analysed according to the grounded theory (Corbin \& Strauss, 2008; Glaser, 1978; Glaser \& Strauss, 1967) using Nvivo software. As we mentioned above, we analysed only the information relating to agility, creativity, and innovation for this paper. We translated ourselves the verbatims. To allow readers to go further if they wish, we have attached the original texts as endnotes. When there is no note, it means that it is the original version of the quote. Otherwise, a number refers to the original verbatim in French or Italian.

Table 2 gives some necessary information on the interviewees' official functions, categorised in broad sector areas, on their nationalities, on the enterprises' significant activities, and their origins. The first column gives a code number used later on to identify the quotes. In the last column, we show the category to which the company belongs: automotive (AU), aeronautics $(A R)$ : or mass production of equipment (PM). More information such as gender, age, number of years working in the company, the number of staff members is also available. Still, we did not consider it relevant for this paper.

Table 2 | List and a short description of respondents (35 managers)

\begin{tabular}{|c|c|c|c|c|c|c|c|}
\hline Code & Title & Function & $\begin{array}{l}\text { Respon- } \\
\text { dent } \\
\text { nationalit } \\
y\end{array}$ & $\begin{array}{l}\text { Country } \\
\text { where } \\
\text { working }\end{array}$ & $\begin{array}{l}\text { Company } \\
\text { activity }\end{array}$ & $\begin{array}{l}\text { Company } \\
\text { nationality }\end{array}$ & Typology \\
\hline A & Cost Director & AS & French & France & $\begin{array}{l}\text { Car } \\
\text { manufacturer }\end{array}$ & French & $\mathrm{AU}$ \\
\hline $\mathrm{B}$ & $\begin{array}{l}\text { Mobility } \\
\text { leader }\end{array}$ & $\mathrm{HR}$ & Russian & $\mathrm{EU}+\mathrm{ASIA}$ & $\begin{array}{l}\text { Car } \\
\text { manufacturer }\end{array}$ & France & $\mathrm{AU}$ \\
\hline $\mathrm{C}$ & $\begin{array}{l}\text { Group Cooperation } \\
\text { Director }\end{array}$ & ST & French & Global & $\begin{array}{l}\text { Car } \\
\text { manufacturer }\end{array}$ & France & $\mathrm{AU}$ \\
\hline $\mathrm{D}$ & Project Manager & PR & Iranian & France & $\begin{array}{l}\text { Car } \\
\text { Manufacturer }\end{array}$ & France & $\mathrm{AU}$ \\
\hline$E$ & $\begin{array}{l}\text { Technical Support } \\
\text { Manager }\end{array}$ & AS & French & $\begin{array}{l}\text { France } \\
\text { Corp }\end{array}$ & $\begin{array}{l}\text { Car } \\
\text { Manufacturer }\end{array}$ & Japanese & $\mathrm{AU}$ \\
\hline $\mathrm{F}$ & Purchasing Director & $\mathrm{PC}$ & Italian & $\begin{array}{l}\text { Italian } \\
\text { Corp }\end{array}$ & $\begin{array}{l}\text { Construction } \\
\text { Equipment }\end{array}$ & Italian & $\mathrm{AU}$ \\
\hline $\mathrm{G}$ & $\begin{array}{l}\text { Manufacturing Vice- } \\
\text { president }\end{array}$ & $\begin{array}{l}\text { PR } \\
\text { Dir }\end{array}$ & Italian & Global & $\begin{array}{l}\text { Construction } \\
\text { Equipment }\end{array}$ & Italian & $\mathrm{AU}$ \\
\hline $\mathrm{H}$ & CE HR Industry & $\mathrm{HR}$ & Italian & Global & $\begin{array}{l}\text { Construction } \\
\text { Equipment }\end{array}$ & Italian & $\mathrm{AU}$ \\
\hline I & $\begin{array}{l}\text { HR Talent } \\
\text { Development }\end{array}$ & $\mathrm{HR}$ & Italian & Global & $\begin{array}{l}\text { Construction } \\
\text { Equipment }\end{array}$ & Italian & $\mathrm{AU}$ \\
\hline$J$ & Plant Manager & PR & Italian & China & $\begin{array}{l}\text { Car } \\
\text { Manufacturer }\end{array}$ & German & $\mathrm{AU}$ \\
\hline $\mathrm{K}$ & $\begin{array}{l}\text { Purchasing Manager } \\
\text { Ext. }\end{array}$ & $\mathrm{PC}$ & German & $\begin{array}{l}\text { Czech } \\
\text { Republic }\end{array}$ & $\begin{array}{l}\text { Car } \\
\text { Manufacturer }\end{array}$ & Czech & $\mathrm{AU}$ \\
\hline L & $\begin{array}{l}\text { Business Dvp and } \\
\text { CRM Manager }\end{array}$ & MKT & French & $\begin{array}{l}\text { Czech } \\
\text { Republic }\end{array}$ & $\begin{array}{l}\text { Car } \\
\text { Manufacturer }\end{array}$ & Czech & $\mathrm{AU}$ \\
\hline M & $\begin{array}{l}\text { Head of Customer } \\
\text { Management and } \\
\text { Rollout }\end{array}$ & MKT & Czech & $\begin{array}{l}\text { Czech } \\
\text { Republic }\end{array}$ & $\begin{array}{l}\text { Car } \\
\text { Manufacturer }\end{array}$ & Czech & $\mathrm{AU}$ \\
\hline $\mathrm{N}$ & $\begin{array}{l}\text { Head of Controlling } \\
\text { Production }\end{array}$ & PR & Czech & $\begin{array}{l}\text { Czech } \\
\text { Republic }\end{array}$ & $\begin{array}{l}\text { Car } \\
\text { Manufacturer }\end{array}$ & Czech & $\mathrm{AU}$ \\
\hline $\mathrm{O}$ & Head of Division & $\begin{array}{l}\text { LG } \\
\text { Dir }\end{array}$ & French & $\begin{array}{l}\text { France } \\
\text { Corp }\end{array}$ & $\begin{array}{l}\text { Automotive } \\
\text { Logistics }\end{array}$ & French & $\mathrm{AU}$ \\
\hline $\mathrm{P}$ & Head of Division & LG- Dir & Spanish & $\begin{array}{l}\text { France } \\
\text { Corp }\end{array}$ & $\begin{array}{l}\text { Automotive } \\
\text { Logistics }\end{array}$ & French & $\mathrm{AU}$ \\
\hline Q & CEO Poland & $L G+D i r$ & $\begin{array}{l}\text { French/Po } \\
\text { rtuguese }\end{array}$ & Poland & $\begin{array}{l}\text { Automotive } \\
\text { Logistics }\end{array}$ & French & $\mathrm{AU}$ \\
\hline
\end{tabular}




\begin{tabular}{|c|c|c|c|c|c|c|c|}
\hline $\mathrm{R}$ & $\begin{array}{l}\text { Senior Vice } \\
\text { President }\end{array}$ & Dir & French & $\begin{array}{l}\text { France } \\
\text { Corp }\end{array}$ & $\begin{array}{l}\text { Automotive } \\
\text { Logistics }\end{array}$ & French & $A U$ \\
\hline $\mathrm{s}$ & $\begin{array}{l}\text { CEO } \\
\text { Czech Rep }\end{array}$ & Dir & French & $\begin{array}{l}\text { Czech } \\
\text { Republic }\end{array}$ & $\begin{array}{l}\text { Aeronautics } \\
\text { Sub-contractor }\end{array}$ & French & AR \\
\hline $\mathrm{T}$ & $\begin{array}{l}\text { Plant } \\
\text { Manager } \\
\text { Mexico }\end{array}$ & Dir & Mexican & Mexico & $\begin{array}{l}\text { Aeronautics } \\
\text { Sub-contractor }\end{array}$ & French & AR \\
\hline$U$ & $\begin{array}{l}\text { Operational Manager } \\
\text { - Structures }\end{array}$ & PR & French & Mexico & $\begin{array}{l}\text { Aeronautics } \\
\text { Sub-contractor }\end{array}$ & French & AR \\
\hline V & $\begin{array}{l}\text { Operational Manager } \\
\text { Interconnection }\end{array}$ & PR & Tunisian & Mexico & $\begin{array}{l}\text { Aeronautics } \\
\text { Sub-contractor }\end{array}$ & French & AR \\
\hline W & $\begin{array}{l}\text { Procurement } \\
\text { Manager Cabin }\end{array}$ & $\mathrm{PC}$ & French & France & $\begin{array}{l}\text { Aeronautics } \\
\text { Manufacturer }\end{array}$ & EU & AR \\
\hline $\mathrm{X}$ & $\begin{array}{l}\text { Customer Quality } \\
\text { Manager }\end{array}$ & MKT & French & France & $\begin{array}{l}\text { Aeronautics } \\
\text { Manufacturer }\end{array}$ & EU & AR \\
\hline Y & $\begin{array}{l}\text { Head of Strategy\& } \\
\text { Business }\end{array}$ & ST & French & France & $\begin{array}{l}\text { Aeronautics } \\
\text { Manufacturer }\end{array}$ & EU & AR \\
\hline Z & $\begin{array}{l}\text { System } \\
\text { Industrialisation }\end{array}$ & PR & $\begin{array}{l}\text { German/ } \\
\text { Mexican }\end{array}$ & Germany & $\begin{array}{l}\text { Aeronautics } \\
\text { Manufacturer }\end{array}$ & EU & AR \\
\hline AA & $\begin{array}{l}\text { Head of } \\
\text { Procurement } \\
\text { Building Const. }\end{array}$ & $\mathrm{PC}$ & Spanish & Germany & $\begin{array}{l}\text { Aeronautics } \\
\text { Manufacturer }\end{array}$ & EU & AR \\
\hline$A B$ & $\begin{array}{l}\text { Sales Director - } \\
\text { South America }\end{array}$ & MKT & French & USA & $\begin{array}{l}\text { Aeronautics } \\
\text { Manufacturer }\end{array}$ & EU & AR \\
\hline AC & $\begin{array}{l}\text { Sales Director - } \\
\text { Europe }\end{array}$ & MKT & Brazilian & France & $\begin{array}{l}\text { Aeronautics } \\
\text { Sub-contractor }\end{array}$ & Sweden & AR \\
\hline$A D$ & $\begin{array}{l}\text { Senior Executive } \\
\text { Operations }\end{array}$ & $\begin{array}{l}\text { MKT } \\
\text { PR }\end{array}$ & Brazilian & UK & $\begin{array}{l}\text { Aeronautics } \\
\text { Manufacturer }\end{array}$ & Canada & AR \\
\hline AE & $\begin{array}{l}\text { External Relations } \\
\text { Director }\end{array}$ & $\mathrm{COM}$ & Canadian & $\begin{array}{l}\text { Canada } \\
\text { Corp }\end{array}$ & $\begin{array}{l}\text { Aeronautics } \\
\text { Manufacturer }\end{array}$ & Canada & AR \\
\hline AF & $\begin{array}{l}\text { Chief Operative } \\
\text { Officer }\end{array}$ & PR & Canadian & $\begin{array}{l}\text { Canada } \\
\text { Corp }\end{array}$ & $\begin{array}{l}\text { Aeronautics } \\
\text { Manufacturer }\end{array}$ & Canada & AR \\
\hline AG & $\begin{array}{l}\text { Head of } \\
\text { Environmental } \\
\text { Affairs }\end{array}$ & ENG & $\begin{array}{l}\text { Canadian/ } \\
\text { Algerian }\end{array}$ & $\begin{array}{l}\text { Canada } \\
\text { Corp }\end{array}$ & $\begin{array}{l}\text { Aeronautics } \\
\text { Manufacturer }\end{array}$ & Canada & AR \\
\hline AH & CEO & $\begin{array}{l}\text { FN } \\
\text { Dir }\end{array}$ & Brazilian & France & $\begin{array}{l}\text { Home } \\
\text { appliances }\end{array}$ & USA & PM \\
\hline $\mathrm{Al}$ & GIS Project Manager & MKT & $\begin{array}{l}\text { Argentinia } \\
\mathrm{n}\end{array}$ & UK & $\begin{array}{l}\text { Home } \\
\text { appliances }\end{array}$ & USA & PM \\
\hline
\end{tabular}

List of functions: AS (after-sales), COM (communication), ENG (engeneeting), FN (finance), HR (HR-Management), LG (logistics), MKT (sales and marketing), PC (purchasing), PR (operation and manufacturing), ST (strategy).

Source: authors

\section{Field results}

Most interviewees agreed that without agility, creativity, and in a second step, innovation could not exist. They described the concept of agility in a way that showed differences according to the functions or the departments, more particularly between sales or procurement and the industrial companies' backbone represented by production and quality.

The examples of quotes shown in Table 3 make clear the fact that production respondents had many more reservations about agility and about the interest in applying the approach to their routine. In the discussion, they were referring to three types of arguments: First, the fact that "[they] are in a big society where business process are mandatories"; Second, the idea that "[the company] cannot use the same approaches like that of start-up societies"; Third, they have a limited perception of agility which is more associated to "short terms, [whereas the company] must work on the contrary on long terms and the best possible use of time and resources." 
Table 3 | agility, a controversial concept (several examples of quotations)

\begin{tabular}{|c|c|c|}
\hline Function & Department & Perception of agility \\
\hline Head of division & Board & "Agility is a fast system to take a decision $(\boldsymbol{P})$ " \\
\hline $\begin{array}{l}\text { Group Cooperation } \\
\text { Director }\end{array}$ & Strategy / Board & "is Ideal for] working cross border "(C) \\
\hline $\begin{array}{l}\text { Procurement } \\
\text { Manager Cabins }\end{array}$ & Sales Department & "We must re-discuss everything " $(W)$ \\
\hline $\begin{array}{l}\text { Chief Operative } \\
\text { Officer }\end{array}$ & $\begin{array}{l}\text { Sales and } \\
\text { Marketing / Board }\end{array}$ & $\begin{array}{l}\text { "A transformation of the [form] of leadership" } \\
\text { "A start-up mode" (AF) }\end{array}$ \\
\hline $\begin{array}{l}\text { Manufacturing Vice- } \\
\text { President } r\end{array}$ & $\begin{array}{l}\text { Operations / } \\
\text { Board }\end{array}$ & "We must transform our mind, ... a slow process "(G) \\
\hline Procurement Director & Procurement & $\begin{array}{l}\text { "The flexible short term } \\
\text { but after long term, we must relook organisation" (F) }\end{array}$ \\
\hline HR director & HRD & "Flexibility helps to manage complexity" $(\boldsymbol{H})$ \\
\hline Production Manager & Operations & $\begin{array}{l}\text { "I understand this word as flexible } \\
\text { It is not applicable is the advantage } \\
\text { but copy the start-up work is not easy." }(N)\end{array}$ \\
\hline $\begin{array}{l}\text { System } \\
\text { industrialisation }\end{array}$ & Operations & $\begin{array}{l}\text { "Agility is [the] execution." } \\
\text { "Before you must analyse very deeply(Z)" }\end{array}$ \\
\hline
\end{tabular}

Source: authors

This approach indicates the importance of a specific job culture (Segal, 2014) that may lead to developing similar objectives and strategies in different companies. To ensure that the concept of "agility" can flourish, companies must set up "disruptive jobs and create a new type of leadership."While understanding the difficulty of the challenge, support functions seemed to be more open to last-minute changes or new customer requests than production or quality, much less flexible.

Generally, to back up the interest in agility, respondents referred to a changing working environment in a perpetual mutation: references, business activity, or even work instructions evolve or differ from place to place: "We are in a global world, but nobody is global. We are all local. Everyone has their perception of things, but it is impossible to know how to implement them!" "What is true today will no more be true tomorrow!"2 Our respondents described what they saw taking place outside their companies: a proliferation of references and their ongoing evolution that imposes a continuous internal bubbling to which each one is participating for fear of being eliminated. "Innovation without agility cannot be successful!"3 Thus, the external context induces a broader view of agility, which encourages managers and their teams to modify behaviours and start changing.

Table 4 shows several excerpts of the discussions emphasising the need for different leadership, i.e., a shared system that must be fearless of mistakes encountered by the teams searching for a new application or a new output.

\footnotetext{
${ }^{1}$ Original versions of verbatim (before translation int English)

On est dan sun monde global,mais personne n'est global. On est local. Chacun a une vision des chose, mais impossible de savir comment les appliquer.

${ }^{2}$ Ce qui est réel aujourd'hui, n'est pas valable dans le futur.

${ }^{3}$ L'innovation sans agileté, c'est voué à l'échec.
} 
Table 4 | The need for a different leadership

\begin{tabular}{ll}
\hline Function & What managers said about leadership... \\
\hline CEO & We must learn while waking; we must listen to the others \\
Communication director & New leaders know that everything is global, but solutions are \\
Sales Director & We must always discuss \\
Operational Manager & We can be agile if we have agile people \\
& Leadership can become important to avoid seeing only \\
Operational manager & operational stuff \\
Procurement Director & To create new values, we must have freedom \\
HRD & Sometimes, companies go for innovation, but the structure is \\
& against it \\
\hline
\end{tabular}

Source: authors

After investigating the requested attitudes, we have created three groups: the "flex-form group," the group of "compromise-seekers," and the "soft power group."

Table 5 | flexibility, compromise-seekers and soft power

\begin{tabular}{ll} 
Type of groups & Comments and quotes \\
\hline Group \#1: Flex-form & "We must first change our behaviours." \\
& "[We need] to reshape whole companies." \\
& "[We must have the] ability to adapt. We have problems every day. \\
We need to move!" & "The word agility means a lot to me. \\
Group\#2: Compromise-seekers & However, I mainly think of looking for a compromise".
\end{tabular}

Group \#3: Soft power "When you are bureaucratic, you lose markets!"

Source: authors

Group\#1: The first solution inevitably calls for the maximum possible flexibility at the individual or organisational levels. It starts with a list of obligations such as "Everything should always be questioned!"4 or "We must first change our behaviours." As it impacts the organisation, it seems necessary "to reshape whole companies." Agility requires "an agile staff," something which can only take place if the whole company "recognises the importance of agility.". In such a context, managers feel obliged to become highly flexible, fit to meet the challenges of a perpetual movement, which does not seem to refer to any specific location: Ability to adapt. We have problems every day. We need to move!" 7

For this first group, agility imposes to be flexible or adaptable,i.e., to adopt the behaviour which will best keep the company in business. Being agile means having alternatives, having a Plan

\footnotetext{
${ }^{4}$ On doit toujours se remettre en question

${ }^{5}$ Remaquiller toute ,organisation.

${ }^{6}$ But, to be agile, we must have our people agile.

${ }^{7}$ Capable de s'adapter. Des problèmes, on en a toujours... II faut bouger!
} 
$\mathrm{B}$, or Plan $\mathrm{C}$, having several solutions for the same project. If contexts change, it will always be possible to pursue a new direction, even if it differs from the first plans.

"Having a plan B does not mean being pessimistic, but just pragmatic." "The frame of reference is continuously changing. Being able to adapt is becoming important!" 9

In this approach, essential elements do not change. However, the change takes place in the implementation. "The way to reach the objective changes, facts do not change!10" Generally, to enhance agility, respondents promoted pro-activity. ("[For me], agility is really similar to proactivity"). The managers of this group recommend a strong implication ("The new leaders are really important [for the development of agility] when they are so"), together with intense relationships with their teams, without forgetting a constant reference to the company's strategic plan.

Group\#2: Managers from the other side of the Atlantic (Canadians, Brazilians, Mexicans) mainly described this second form of implementation "The word agility means a lot to me. However, I mainly think about compromises"11. Interestingly, none of the numerous French managers that we interviewed mentioned the word "compromise." Indeed, the literature (D'Iribarne, 1987; Romano et al., 2011) has shown that in France, this word always denotes the idea of a "soft compromise," meaning an action without vigour that could be the sign of a significant setback.

On the contrary, when interviewees link compromise to agility, they refer to the idea of listening to others (Dupuis, 2008), silencing their individuality to give precedence on other points of view to act differently, maybe with a more reasoned, logical, common-sense approach. Changing, in this case, should mainly lead to an entirely new approach to a significant drop in procedural aspects, described as "bureaucratic," to make it possible to adopt a behaviour better suited to deal with the problem quickly and efficiently. "When you are bureaucratic, you lose markets. ${ }^{12}$,

Group\#3 is linked directly to the idea of changing the approach by using new soft methods. In a globalised and competitive environment, agility means running against the tide, letting our natural trends express themselves. "If you are a company which is fighting for financial stability, you'd rather be more bureaucratic!"13 Being agile may lead you to do the opposite of what you would consider normal, letting yourself be carried away by the teams' creativity towards something close to a start-up's ways of doing. Because operating like a start-up implies developing an entrepreneurship spirit. "You need to keep some entrepreneurship spirit, the true spirit that your company had when it started."14 This behaviour goes with the manager's commitment as well as their unfailing motivation, causing employees' empowerment to become a fundamental element and a robust competitive lever.

${ }^{8}$ Toujours avoir un plan $\mathrm{B}$, cela ne signifie pas être pessimiste mais être pragmatique

${ }^{9}$ Le référentiel continue de changer et donc s'adapter devient important

${ }^{10}$ La manière d'arriver change...les choses ne changent pas.

${ }^{11}$ Le mot agilité me dit beaucoup de choses, mais [il] me fait penser surtout au compromis

12 Quand vous êtes bureaucratique, vous perdez les marchés

${ }^{13} \mathrm{Si}$ vous êtes une compagnie qui rame au sens des revenus, vous devez être plus bureaucratique

${ }^{14}$ Il faut garder et maintenir un peu l'esprit entrepreneurial que votre société avait au début 
Furthermore, most respondents of the third group emphasised the role of managers and their behaviours towards their staff: "[agility] depends on [the] mentality of the people. If they are open, they take advantage, if not, they see the limits of [perpetual change]", or "To make agility efficient, you need to understand people!"15

As a general rule, the three groups highlighted the role of international managers as key-drivers of the change of attitude. This view comes in contrast with the position of several Top Managers or consultants who see agility as "a process used to push teams who do not have the resources to act [at any cost] instead of helping them to understand." ${ }^{16}$ Agility is indeed often used to ignore problems instead of bringing support to employees. "Today, we talk of agility for all kinds of things. "17

Close to the positive perception of agility, we find a darker aspect that might lead individuals to generate a new type of actions, without a precise goal or a clear justification, doing almost anything except what would be necessary. This understanding of the scope of the concept may have blocked its development, such as when Airbus removed it from the leadership model's core values because they considered it was becoming a buzzword and that it created confusion with the agile methodology. We can also mention trade-unions and philosophers, groups ignoring the industry back-grounds. They often criticise the entrepreneurial reality: seeing continual changes as depriving workers of any clear perception of their future and a way to impose a development they would not accept.

Nevertheless, ensuring a rapid outcome to all projects has become a necessity, and the continued appetite for fast results has led companies to prefer small step progress, leading innovations to become an addition of shorts sprints. Projects are changing "...with short intensive phases and intensive phases... Each week, we need [to] deliver something, and we can get very concrete examples, have different sections go with the flow."18

This practice entails the risk that several projects will be blocked for an economic reason after a series of small successful mini phases, without any reasonable assurance that they will come to an end. Such a development might blur the employees' perception of the company's longterm strategy. "We have many micro-projects with which we end up at $80 \%$ of the results, but not $100 \% . " 19$ It may also alter the employees' trust and demotivate them.

Several respondents declared to be willing to accept these limitations because of the stringent necessity to decide faster using available information. "For the decision-making, we do not have a lot of information...It obliges us to ride the wave." 20 . Managers and employees must accept to make decisions with less preparation. "...we must prepare ourselves, but this does not work

\footnotetext{
${ }^{15}$ Pour que l'agilité devienne efficace, il faut comprendre les gens

16 ...pour dire à des équipes qui n'ont pas les moyens d'y aller [à n'importe quel prix], et non pour faire comprendre.

${ }^{17}$ Aujourd'hui, on parle d'agilité pour faire n'importe quoi !

18 ....avec des phrases courtes et intensives...chaque semaine on doit livrer quelque chose, et on peut avoir rapidement du concret...avoir des morceaux au fil de l'eau.

${ }^{19} \mathrm{Ce}$ sont toujours [des] micro-projets [pour lesquels] on va vite sur $80 \%$ du résultat et non pas sur le $100 \%$ !

${ }^{20}$ Dans la prise de décision, on n'a pas beaucoup d'informations...cela nous oblige à surfer sur la vague...
} 
with agility." ${ }^{21}$ Most of [the] time, the timeliness of decision making is directly related to the time devoted to the preparation. In such a context, it is essential to avoid misunderstandings: "...sometimes, it is confusion. The agility does not mean less quality, but it is a cunning [to get] things faster". The approach allows us to create shorter cycles, to eliminate waste of time, and get quick returns."

The respondents mentioned several recommendations, among which we find the necessity to share with the team. "For agility to become efficient, it needs to be understood by your people."22 "It must become the team's normal behaviour." This comment highlights the fact that agility is more than the product of individual thinking, but instead the consequence of a team reflection echoing the effort done to develop creativity and innovation. "Without agility, innovation fails" ${ }^{23} \mathrm{It}$ is a gradual process that highly depends on the commitment of the team. "You need to learn by doing!". ${ }^{24}$

Many interviewees described creativity as the ability to "move without using a trapeze," which is to break free from the usual frame and to be able to act most efficiently. It cannot be the privilege of a few individuals endowing unique attributes, but it is an essential team challenge. "I don't think [that] what you want is something natural. [It does not happen] if you don't change their capacity". To make creativity happen, the team must use the best of its collective ability and combine the qualities of each member. This necessary endeavour highlights the role of the manager, who needs to explain the strategic vision of the company and give the team the framework within which they will place their efforts. "This is essential because it is expected that the manager has a vision...The team often has their noses to the grindstone!"25. The latter should be able to "explain the strategy and its different potential applications. He must help the locals to express their creativity."26

Consequently, one of the main objectives of the manager is to set up the framework while encouraging a multicity of proposals. "[The manager] must choose a framework, but he must give the highest freedom to ideas because there is more than one way to apply and implement..."27 He must listen to them and help the team move upwards to help them. "To help other people, I push, and I have limits!". "You must be able to listen to your team if you are a manager!". 28 "You must also "identify, motivate, and recognise those who are going beyond the tasks they are supposed to achieve."29

All this shows the complexity of the manager's role: on the one hand, he must bring his team to move a step backward and dedicate time to thinking out, and on the other hand, Top

\footnotetext{
${ }^{21}$ On doit se préparer à ce que cela ne marche pas avec l'agilité

22 Pour que l'agilité devienne efficace, il faut qu'elle soit comprise par les gens.

23 Sans agilité, l'innovation est vouée à l'échec

24 On doit apprendre en marchant

${ }^{25}$ Important, car au manager on demande une vision...Les équipes sont souvent prises la tête dans le guidon.

26 ...faire comprendre la stratégie et sa déclinaison, et faire exprimer le local dans toute sa créativité.

${ }^{27}$ In un team, decidere un framework e lasciare libertà a delle proposte . L'esecuzione delle proposte puo' essere fatta in tanti modi!

${ }^{28}$ Vous devez être capable d'écouter si vous êtes un manager.

${ }^{29}$ Reconnaître, motiver et faire évoluer les gens ; reconnaître qui a été au-delà de sa tâche.
} 
Management expects him to welcome any attempt to innovate and support it. To be able to accomplish this task, it is essential to know how to cross-fertilise the team's creative playground and to stabilise their behaviours. And all this work cannot be fully efficient if the company does not construct the appropriate environment.

Now, what are managers doing to enhance creativity? The answers go in three directions: the use of specific instruments, changing approaches, and the fight against bureaucracy.

The interviewees were not particularly innovative when mentioning instruments to use. They cited inter-functional meetings, workshops, and brainstorming. All three methods aim at sharing ideas, discuss several concepts, and finally at enhancing the emergence of new notions. Several companies, often smallest, have built dedicated structures called "creative factories." "...the creative factory is the basis for the future. Without innovation, [there is] no future." Crosscutting meetings gathering people from different divisions are often essential to look beyond its category, break free from its frame, and discover new ideas. In some companies (for example, Airbus, Renault), the development of the latter method might be a consequence of the increased number of function managers whose teams vary according to the needs of the company.

The second set of actions is an expansion of the first one, with a stronger imperative to open up new horizons. We find here the "openness" that Caligiuri $(2000 a, b)$ expects from international managers, a feature necessary to help team members to see things in a different way (cross-fertilisation). One decisive initiative, among others, is to train them about subjects not useful for their occupation, such as production for finance specialists or finance for quality experts. One of the managers mentioned that "the Mexican Team...is very dynamic" in comparison to other subsidiaries in the group. Managers also said searching outside companies. "Sometimes, we search outside the organisation....", and even "teach people is not only technical, but also to propose [that] someone could organise something, a trip together for a change, and [help people develop]." In such a situation, the fundamental function of the manager is to give the team a strategic vision. "We need to have a "project management without the need of paying attention to this, something that [allows us] to act and go forward." 30

Furthermore, it essential that the leader becomes an example as a way to influence the team and create the best possible situation. "The leader influences the team"... "He must create the conditions before [innovative ideas] and implement them afterwards." 31 The problem is that the manager needs to give a starting framework, but that he must also accept the craziest ideas to avoid drying up the flow. "He must define the framework but leave then everything open because the possible answers can take many different forms." 32

The respondents also mentioned a third condition which consists of the avoidance of processes and controls. The subordinates must feel free if we want them to go beyond limits that seemed up to now impossible to exceed. "To push: always doing the same thing... and we must do what

\footnotetext{
${ }^{30}$ Nous avons besoin d'avoir un 'project management' sans se retourner, mais qui nous permette de faire tout en avançant.

${ }^{31}$ Deve creare le condizioni e dopo farlo.

32 II doit décider du cadre et, après, laisser libre les propositions ; car la déclinaison peut être fite en beaucoup de façons différentes.
} 
[we] ask the team". "They must be driven but not smothered." 33 This links to another perception of the same type: "If I accept to lose control, I open myself to innovation." 34 "

Innovation is about letting go of control. We can link it to the production or a process, but it is what ensures that "people will still be here in 5 years." 35 Consequently, the manager becomes an interface between his/her team and the direction, between the desire to innovate and the "status quo". Indeed, if many companies declare to be prepared to innovate, few respondents described the automatic trend that puts on the side all actions enhancing creativity and instead increases bureaucratic control. This conflict might be more important in Germany: "Innovation in Germany. You have an idea, and you need to be fast. And, right after, this idea can fire you." "When a company is interested only in the results, it freezes all actions." 36 The problem can be even more visible during a period of crisis because everything might be done to reduce costs and experimentations.

Not only must global managers find the right balance between freedom and control! They must also be open enough to welcome all new ideas positively. "[According to me], the feature he needs to have is an open mindset....and this is certainly most difficult!" Several presented this latter characteristic as being essential when you want to trigger an innovation cycle.

It might even be more challenging to accept that the subordinate, while trying to innovate, may make mistakes and fail. Such risk obliges leaders to take the method of trial and error, most often vilified during their education. And they also need to battle with risk-averse directions. "You need to accept that there will be mistakes and failures!". ${ }^{37}$ Our analysis showed that the best-organised innovation policies might fail because of the organisational context. You need to support employees if you want to implement new ideas. But you must accept the risk that not all of them will be successful.

The Boards are still afraid of failures because they might endanger their image and their strategic vision. However, the notion of agility obliges managers and business leaders to review their approaches. Acting with less preparation may inevitably lead to errors. It will be one of the biggest challenges of the 2.0 corporation.

\section{Discussion and conclusion}

In this paper, we wished to look deeply at how international managers working in multicultural corporations can participate in changing working processes with their teams and within their companies. Even in the case of organisations that are pushing towards more freedom of thought and creativity, the actions often clash with organisational cultures that tend to block new initiatives. In this context, we need to understand what the contribution of international managers can be and how their actions can be most effective.

Our analysis has shown an active link between the concept of "agility" and those of creativity and innovation. One of the managers interviewed considers that "agility is present [at all

\footnotetext{
33 Elles doivent être drivées mais pas étouffées.

34 Se accetto di perdere controllo, apro all'innovazione.

${ }^{35}$ Cet état représente le motif qui fera en sorte que les gens seront encore là dans 5 ans.

${ }^{36}$ Quand une compagnie n'est intéressée que par les résultats, elle se crispe...

37 Vous devez accepter qu'il y ait des erreurs et des échecs.
} 
moment of a company's life], while innovation arises in the long term."38 The concept of "agility" is the direct result of an international environment that cannot be fixed or imagined. In such a context, it becomes necessary for any company to adapt to new constraints and requests throughout its existence and adopt an attitude flexible enough to ensure continued business development and the ability to meet customer requirements.

Most interviewees said that "the world has changed," that the environment was constantly changing and that the ability to adapt was becoming a fundamental asset. The question that arises is whether this development is inevitable or whether it is the consequence of the perception of international companies which have chosen to participate in the "global development." The answer is hard to establish, especially since the people interviewed are executives or leaders, educated to conquer foreign markets, marked by this specific philosophy, and by the vision of the companies that employ them. One might wonder whether this perception of a world in perpetual motion is a good translation of reality or whether it is a mere transcription of the judgment of MNCs which use it to impose unlimited flexibility and a type of enslavement to their employees.

Few voices were raised in the interviewed population to criticise the concept of agility. Production engineers and, in other functions, few French, Czech, or German managers voiced heavy critics against the idea. The reaction seemed to be influenced by a professional culture that feels obliged to step back and assess the impact that simplifying manufacturing procedures might have on quality. Some engineers reacted: "Qualification is the sign of professionalism"39 or "The quality manager cannot be in this conception, we cannot always be quick and act in an agile manner ...". 40 This vision also rejects the amalgam often mentioned with start-ups. "We cannot act like a start-up! we are a very big company!"41 This manager also insisted, particularly on the fact that it is impossible to deviate from existing procedures and to go towards a "chimaera."

In the cases of critics coming from German managers, previous literature has shown the influence of the national culture in a secure request for the strictest possible framework before starting any actions (D'Iribarne, 1987). On another note, the French criticism relates more often to position changes, a situation that prevents any constitutive bond and any strong relations between employees or between employees and managers. A manager indicated that "this natural bubbling characteristic of [many] companies was the consequence of a strategy which tried to prevent the creation of too strong emotional ties" between the employee and their boss.

Other managers have described a different vision of agility, distinguishing it from everyday activities. "Today, we use this name to do anything!"42 or worse "to get teams to perform any action and in any way." 43 If this flexibility is considered necessary, there is a risk of distorting

\footnotetext{
38 ...l'agilité est présente [à tout moment], tandis que l'innovation,[c'est ce qui se présentera dans le] long terme.

${ }^{39}$ La qualification es tle signe du professionalisme

${ }^{40}$ Le responsable qualité ne peut ps être dans cette conception; on ne peut pas être toujours rapide et agir de façon agile!

${ }^{41}$ Nous ne pouvons pas agir comme une startup. Nous sommes une très grande entreprise.

${ }^{42}$ Aujourd'hui, on utilise ce nom pour faire n'importe quoi!

43 ...pour faire exécuter aux équipes n'importe quelles actions, et de n'importe quelle manière.
} 
the usual operation. Several persons mentioned a few IT projects which were left uncompleted. The funding running out, Top Management decided to stop everything despite the expectations and the hours worked by all people involved. Interviewees who have been going through this situation felt they were very disappointing and demotivating experiences! Consequently, it is essential to realise that MNCs may have wanted and organised this move towards more agility to isolate workers and their demands. Our interviews do not provide us with enough information to decide.

Many presented the emergence of creativity as essential for the sustainability of companies. Discussions converged towards the idea that creativity appears when there is a confluence of three elements: the absence of bureaucratic control, the freedom to make mistakes for employees embarked on the search for flexibility, as well as the possibility of taking up innovations internally or externally.

Several interviewees presented excessive control focused on all aspects of the job as an evident barrier. Too much "hard control" seemed to be killing the emerging tendencies to seek new ways of working. Here, the manager's role became precious: "framing, without controlling," "being able to leave enough freedom for his proteges," and not "overheating them." This behaviour showed out as essential, especially in the second phase, which allows team members to learn from mistakes. This process of trial and error is generally not well experienced in business, both by the protagonists and by the managers. The latter, in the event of financial problems, prefer to reduce costs than to seek new solutions.

Many respondents mentioned their internal contradiction as managers who perceive innovation as an essential key to the future but who do not hesitate to consider that errors are strong attacks on the operating account. Thus, international managers must help find the best compromise, defend their teams, and become the advocates of a new form of entrepreneurship. A Canadian manager took up this contradiction and declared: "We must be open to accepting innovation." According to him, "it is the empowerment that makes the difference ... if you have looked for this in your team, you must accept that there are mistakes and failures". ${ }^{4}$

The last point mentioned concerns the possibility of discussing with a larger group ("brainstorming") about the objectives, the planning, the program, and above all, the results. It essentially allows people to exchange ideas and learn from mistakes. Many interviewees stressed the importance of these moments when everyone could trade with other departments of the same company, or also with people from companies in different fields. Mainly, these opportunities allowed them to bring in a new spirit, a critical eye, and new ways of doing things.

At this point, we would highlight three crucial questions: 1 . What is the relevance of logic, leading to a request for more agility and more creativity at all levels of the organisation? 2. How should the relations between international managers and their subordinates be organised to make the surge towards more creativity possible? 3 . How successful was the attempt to break with the highly structured MNC's operations?

First, the concept of agility seeks to transform the organisation and adapt it to a changing environment. But is the resulting bubbling caused by the external environment? Or is it an initiative of the companies themselves, which would thus seek to limit social ties by depriving

44 On doit être ouvert pour accepter l'innovation...c'est l'empowerment qui fait la différence...si vous avez cherché cela dans votre équipe, vous devez accepter qu'il y ait des erreurs et des échecs. 
individuals of solidarity? Our interviewees did not provide an answer to this question. Also, they remained relatively unspoken about contextual reasons. The global environment would have changed, becoming more sophisticated, bringing in its wake the need to adapt, streamline behaviour, and bet on responsiveness rather than long-term plans. We remain on this point a little on our interrogation. While taking into account the influence exerted by these changes of contexts, it would be interesting to observe the attitude of the management of companies and to put it in parallel with the behaviour of the new generations, raised in the immediacy more than in the reflection.

The second question relates more to management. It consists of asking how to develop creativity within a team. We saw that most interviewees put at the centre of their concerns the vertical relationship between managers and subordinates. Should it always be hierarchical and thus take advantage of aspects of control? Or, on the contrary, should managers be at the periphery of the action, providing a framework and giving the necessary indications to the team? It is undoubtedly useful to go further around this question. The problem will arise tomorrow of knowing where to stand between vertical and horizontal coordination. Notably, it remains to be seen whether the horizontal approach is more comfortable to implement in cultures with a low hierarchical dimension. To go deeper into this reflection, we suggest launching an analysis of our data to check possible connections between the origin of managers and their feelings and opinions about necessary changes in hierarchical links.

Still, on management, many interviewees stressed that companies make excellent speeches but that their actions are not always consistent. Particularly, directions are said to accept mistakes, but they have great difficulty in doing so, whereas it seems impossible to innovate without making mistakes. This contraction is the same as that which prevents researchers from examining the failures of companies: most hide them while preferring to speak of their successes. Employees and managers are supposed to learn from mistakes to avoid making them again, but the company rarely allows it.

The third point was how much creativity and innovation were present in the daily lives of managers and stopped being concepts of literature. Innovation has become a competitive lever for all companies, whether they like it or not, even when it means "being overtaken." Creativity resulting in innovation is what "allows [companies] to be here in five years." and what guarantees the long term of companies: "who wants to survive must become innovative."

Innovation can affect products (this is the only innovation that production engineers know about), but it can also lead to new procedures or unexpected work systems. Its scope becomes more extensive than before, and everyone, depending on their skills, can participate. It is a continuous innovation based on the concept of the Deming wheel and constant improvement. In reality, this perception brings us back to Norbert Alter's concept of "Ordinary innovation" (Alter, 2015).

The question now is how to go further and what to do with this information collected in our research. We can already imagine an evident managerial fallout. This information can form the basis of a training or coaching program for international managers. Given the increasing complexity of the task, it is vital to help the people concerned to express themselves without taboos, to talk about their possible difficulties, and to imagine changes in the operating mode.

Furthermore, we consider that this paper was a kind of exploratory work. There are still many areas to be examined in more detail. For example, it would be interesting to understand better 
the link between national cultures and the openness to agility and creativity. Do some cultures accept the idea of change more readily? And which cultures accept mistakes in the search for innovation?

In the same way, it would be interesting to ask the same questions about corporate cultures. And even wonder if there are cultures that would be more compatible with a start-up operation. These questions could give rise to qualitative or quantitative research. In the latter case, the items to be asked and the manner of asking them would flow directly from experience acquired during the in-depth semi-structured interviews.

A final point deserves further study. It concerns the operating dynamics of innovations within companies. What are the factors favouring this development and those who risk blocking it? We could, of course, find here elements linked to the various types of culture but also political or sociological aspects. The only way to recover information going in this direction would be to make an in-depth qualitative study foreseeing numerous interviews within one to a maximum of three different companies.

\section{References}

Alter, N. (2015). L'innovation ordinaire. Paris: Presses universitaires de France.

Amabile, T. M. (1996). Creativity and innovation in organisations, HBS Case Collection, Boston: Harvard Business School Press.

Amabile, T. M., \& Pratt, M. G. (2016). The dynamic componential model of creativity and innovation in organisations: Making progress, making meaning. Research in Organisational Behavior, 36, 157-183.

Aretz, H. J., \& Hansen, K. (2003a). Erfolgreiches Management von Diversity. Die multikulturelle Organisation als Strategie zur Verbesserung einer nachhaltigen Wettbewerbsfähigkeit. German Journal of Human Resource Management, 17(1), 9-36.

Aretz, H. J., \& Hansen, K. (2003b). Diversity Management-ein Konzept für den Umgang mit Vielfalt und Komplexität, Research Article, German Journal of Human Resource Management, 17(1), 9-36.

Barro, R. J., \& Lee, J. W. (2015). Education matters. Global schooling gains from the 19th to the 21st century. Oxford: Oxford University Press.

Bhatt, G., Emdad, A., Roberts, N., \& Grover, V. (2010). Building and leveraging information in dynamic environments: The role of IT infrastructure flexibility as enabler of organisational responsiveness and competitive advantage. Information \& Management, 47(7-8), 341-349.

Bouwman, H., Nikou, S., Molina-Castillo, F. J., \& de Reuver, M. (2018). The impact of digitalisation on business models. Digital Policy, Regulation and Governance, 20(2), 105-124. https://pure.tudelft.nl/portal/files/54073154/DPRG_07_2017_0039.pdf.

Caligiuri, P. M. (2000a). The big five personality characteristics as predictors of expatriate's desire to terminate the assignment and supervisor-rated performance. Personal psychology, 53(1), 67-88.

Caligiuri, P. M. (2000b). Selecting Expatriates for Personality Characteristics: A Moderating Effect of Personality on the Relationship Between Host National Contact and Cross-cultural Adjustment Management International Review, 40 (1-2000 1st Quarter), pp. 61-80.

Caligiuri, P. M., Mencin, A., \& Jiang, K. (2013). Win-win-win: The influence of company-sponsored volunteerism programs on employees, NGOs, and business units. Personnel Psychology, 66(4), 825860. 
Cazorzi, C. (2018). Integration strategy of Italian expatriates in French market: a case history. Advances in economy and business management, Thesis of Doctorate, Paris: Université PSL.

Chakravarty, A., Grewal, R., \& Sambamurthy, V. (2013). Information technology competencies, organisational agility, and firm performance: Enabling and facilitating roles. Information systems research, 24(4), 976-997.

Chen, Y., Wang, Y., Nevo, S., Jin, J., Wang, L., \& Chow, W. S. (2014). IT capability and organisational performance: the roles of business process agility and environmental factors. European Journal of Information Systems, 23(3), 326-342.

Corbin, J., \& Strauss, A. (2008). Strategies for qualitative data analysis. Basics of Qualitative Research. Techniques and procedures for developing grounded theory, 3, Juliet Corbin \& Anselm Strauss, Sage Publications.

D'Iribarne, P. (1987). Ce qui est universel et ce qui ne l'est pas. Revue française de gestion, 64, 6-9.

Dupuis, J. P. (2008). Culture et gestion au Québec: entre cultures latine, anglo-saxonne et nordique. Gestion en contexte interculturel: approches, problematiques, pratiques et plongées, 1-45, Université Laval.

Ettlie, J. E. (2019). Innovation Renaissance: Defining, Debunking and Demystifying Creativity. Routledge.

Fetrati, M. A., \& Nielsen, A. P. (2018). The association between creativity and innovation: A literature review. In ISPIM Conference Proceedings (pp. 1-14). The International Society for Professional Innovation Management (ISPIM).

Glaser, B., \& Strauss, A. (1967). The discovery of grounded theory. Weidenfield \& Nicolson, London, 1-19.

Glaser, B. G. (1978). Theoretical Sensitivity, The Sociology Press

Glăveanu, V. P. (Ed.). (2017). The Palgrave handbook of creativity and culture research, London: Palgrave.

Glăveanu, V. P. (2015). Creativity as a sociocultural act. The Journal of Creative Behavior, 49(3), 165-180.)

Grahl, J. (1985). Creative destruction: the significance of Schumpeter's economic doctrines. Cahiers d'économie politique/Papers in Political Economy, №10/11, 213-227.

Harrison, C. A. (2012). The Impact of the Standards Movement on Creativity and Imagination as Perceived by Fine Arts Teachers (Doctoral dissertation, Walden University).

Khan, H., \& Wisner, J. D. (2019). Supply Chain Integration, Learning, and Agility: Effects on Performance. Journal of Operations and Supply Chain Management, 12(1), 14.

Kirton, M. J. (2004). Adaption-innovation: In the context of diversity and change. London: Routledge.

Lee, T. S., \& Mumford, D. (2003). Hierarchical Bayesian inference in the visual cortex. JOSA Publishing, 20(7), 1434-1448.

Machado, C. F., \& Miranda, R. M. M. (2020). About Competencies, Creativity, and Innovation in the Portuguese Textile and Clothing Sector. In Entrepreneurship and Organizational Innovation (pp. 93112). Springer,

Madjar, N., Greenberg, E., \& Chen, Z. (2011). Factors for radical creativity, incremental creativity, and routine, non creative performance. Journal of applied psychology, 96(4), 730.

Mohamed, M. S., Khalifa, G. S., Al-Shibami, A. H., Alrajawi, I., \& Isaac, O. (2019). The Mediation Effect of Innovation on the relationship between Creativity and organisational productivity: An empirical study within public sector organisations in the UAE. Journal of Engineering and Applied Sciences, 14(10), 3234-3242. 
Narel, R. L., Yaeger, T., \& Sorensen Jr., P. F. (2019). Exploring Agile Thriving Teams in Continuous Change Environments. Research in Organizational Change and Development, 187-211.

Ouchi, W. G. (1980). Markets, bureaucracies, and clans. Administrative science quarterly, 129-141.

Paulus, P. B., \& Nijstad, B. A. (Eds.). (2019). The oxford handbook of group creativity and innovation. Oxford: Oxford Library of Psychology.

Pesqueux, Y., \& Tyberghein, J. P. (2010). L'école japonaise d'organisation. Innovations, (1), 11-31.

Roberts, N., \& Grover, V. (2012). Leveraging information technology infrastructure to facilitate a firm's customer agility and competitive activity: An empirical investigation. Journal of Management Information Systems, 28(4), 231-270.

Romano, S., Lazar, M., \& Canonica, M. (2011). L'Italia disunita (Vol. 540). Longanesi.

Rosing, K., Frese, M., \& Bausch, A. (2011). Explaining the heterogeneity of the leadership-innovation relationship: Ambidextrous leadership. The leadership quarterly, 22(5), 956-974.

Sambamurthy, V., Bharadwaj, A., \& Grover, V. (2003). Shaping agility through digital options: Reconceptualising the role of information technology in contemporary firms. MIS quarterly, 23(2), 237263.

Schein, E. H. (1990). Organisational culture, Ameican Psychologist 45 (2), 109-110.

Schein, E. H. (2010). Organisational culture and leadership (Vol. 2). Hoboken (NJ): John Wiley \& Sons.

Segal, J. P. (2014). Efficaces, ensemble. Un défi français. Paris: Le Seuil.

Sherehiy, B., Karwowski, W., \& Layer, J. K. (2007). A review of enterprise agility: Concepts, frameworks, and attributes. International Journal of industrial ergonomics, 37(5), 445-460.

Smircich, L. (1983). Concepts of culture and organisational analysis. Administrative science quarterly, 339358.

Swafford, P. M., Ghosh, S., \& Murthy, N. (2008). Achieving supply chain agility through IT integration and flexibility. International Journal of Production Economics, 116(2), 288-297.

Tallon, P. P., \& Pinsonneault, A. (2011). Competing perspectives on the link between strategic information technology alignment and organisational agility: insights from a mediation model. Mis Quarterly, 35(2), 463-486.

Tan, K. H., Ji, G., Lim, C. P., \& Tseng, M. L. (2017). Using big data to make better decisions in the digital economy. International Journal of Production Research, 55(17), 4998-5000.

Tan, B., Pan, S. L., Lu, X., \& Huang, L. (2009). Leveraging digital business ecosystems for enterprise agility: The tri-logic development strategy of Alibaba. Conference: Proceedings of the International Conference on Information Systems, ICIS 2009, Phoenix, Arizona, USA, December 15-18, 2009

Thiruvenkadam, T., \& Kumar, K. S. (2018). ORGANISATIONAL CLIMATE FOR INNOVATION AND CREATIVITY. BVIMSR's Journal of Management Research, 10(2), 165-173.

Vickery, S. K., Droge, C., Setia, P., \& Sambamurthy, V. (2010). Supply chain information technologies and organisational initiatives: complementary versus independent effects on agility and firm performance. International Journal of Production Research, 48(23), 7025-7042.

Zain, M., Rose, R. C., Abdullah, I., \& Masrom, M. (2005). The relationship between information technology acceptance and organisational agility in Malaysia. Information \& Management, 42(6), 829-839.

Zheng, W., Khoury, A. E., \& Grobmeier, C. (2010). How do leadership and context matter in R\&D team innovation? A multiple case study. Human Resource Development International, 13(3), 265-283. 
The research paper passed the review process. | Received: April 23, 2020; Revised: June 3, 2020; Accepted: June 14, 2020; Pre-published online: December 7, 2020; Published: March 19, 2021.

\section{Appendix}

\section{Grid from Ground Theory}

We have divided (broken down) this table by topics, categories, characteristics, and finally, the practitioner's consequences as they told us. On this. The "Field Results" you can read in the analysis (part 3 )

\begin{tabular}{|c|c|c|c|}
\hline TOPIC & categories & caracteristics & Consequences \\
\hline \multirow[t]{3}{*}{ AGILITY } & fast decision & $\begin{array}{l}\text { cross border importance } \\
\text { cross-country } \\
\text { communication }\end{array}$ & $\begin{array}{l}\text { way out } \\
\text { cross functionalism }\end{array}$ \\
\hline & $\begin{array}{l}\text { Leadership } \\
\text { change }\end{array}$ & $\begin{array}{l}\text { organisational change } \\
\text { new manager functions } \\
\text { manager new importance }\end{array}$ & $\begin{array}{l}\text { education to adapt } \\
\text { Flexibility } \\
\text { Feedback importance }\end{array}$ \\
\hline & not acceptable & $\begin{array}{l}\text { only for doing } \\
\text { we are not a start-up, } \\
\text { industry }\end{array}$ & $\begin{array}{l}\text { a lier to do what you would like } \\
\text { procedure first }\end{array}$ \\
\hline
\end{tabular}

\begin{tabular}{|c|c|c|c|}
\hline TOPIC & catégories & caracteristics & Consequences \\
\hline \multirow[t]{3}{*}{ CREATIVITY } & Vision & $\begin{array}{l}\text { Harness } \\
\text { Driver }\end{array}$ & $\begin{array}{l}\text { Brainstorming } \\
\text { pushing in new direction }\end{array}$ \\
\hline & Futur & $\begin{array}{l}\text { crossfertilization } \\
\text { let us to mistake }\end{array}$ & $\begin{array}{l}\text { batir pour partager } \\
\text { Freedom }\end{array}$ \\
\hline & contradictions & $\begin{array}{l}\text { control without freedom } \\
\text { motivation'distruction }\end{array}$ & $\begin{array}{l}\text { no innovation } \\
\text { acceptancy of mistaking }\end{array}$ \\
\hline
\end{tabular}




\begin{tabular}{|c|c|c|c|}
\hline TOPIC & Catégories & caracteristics & Consequences \\
\hline \multirow[t]{4}{*}{ INNOVATION } & consumer expectations & manager role & innovating approach \\
\hline & Step by step & $\begin{array}{l}\text { little step big } \\
\text { innvation }\end{array}$ & encouraging people \\
\hline & & importance of details & Endorse \\
\hline & different attitude & openess & $\begin{array}{l}\text { to the strange, inusual } \\
\text { shared intelligence }\end{array}$ \\
\hline
\end{tabular}

